\title{
THE INSIDE VIEW ON MAKASSAR'S 16TH TO 17TH CENTURY HISTORY: CHANGING MARITAL ALLIANCES AND PERSISTENT SETTLEMENT PATTERNS
}

\author{
David Bulbeck ${ }^{*}$ \\ Department of Archaeology and Natural History, \\ College of Asia and the Pacific, \\ Australian National University, Canberra ACT 0200, Australia \\ email: david.bulbeck@anu.edu.au
}

Published online: 15 September 2016

To cite this article: Bulbeck, D. 2016. The inside view on Makassar's 16th to 17th century history: Changing marital alliances and persistent settlement patterns. In Orality, writing and history: The literature of the Bugis and Makasar of South Sulawesi, ed. Druce, S. C. International Journal of Asia Pacific Studies 12 (Supp. 1): 143-167, http://dx.doi.org/10.21315/ijaps2016.12.s1.7

To link to this article: http://dx.doi.org/10.21315/ijaps2016.12.s1.7

\begin{abstract}
The alliance of the Makasar-speaking kingdoms of Gowa and Talloq elevated Makassar to the status of an empire before its conquest in 1667 by the Dutch in alliance with the Bugis, Makassar's local enemies. In my previous research I recognised three main phases in Makassar's history: a growth phase (circa 1500-1593) when Gowa expanded territorially, cemented by the marriage of local princesses into the royal Gowa line; a consolidation phase (1593-1667) characterised by reciprocal marital exchange between Gowa and Talloq and their surrounding polities; and a disintegration phase (1667-1700) when Gowa and Talloq became givers rather than takers of princesses. Recent translations into English by William Cummings of the texts on which I based my analysis provide the opportunity to test the validity of my three-phase scenario. Further, how political relations changed during the first two phases can be illustrated through reconstructing the geopolitical landscape of Makassar and its hinterland at four time slices: the early and middle 16th century, and the early and middle 17th century.
\end{abstract}


Keywords: Makassar, South Sulawesi, Gowa, Talloq, historical archaeology, indigenous texts

\section{INTRODUCTION}

During the early 17 th century, Makassar $^{1}$ obtained international renown as the centre of an empire that dominated southwest Sulawesi and exerted major political, economic and cultural influence on the islands to the east. The main economic basis for the empire's supremacy in Sulawesi was its role as a hub for the west to east trade of valuable manufactured goods and the east to west trade of the Moluccan spices and other primary produce. At the time, the Dutch East India Company (VOC) was attempting to monopolise the trade in highly lucrative eastern Indonesian spices, and Makassar harboured traders who continued to trade in these items in defiance of the VOC's aims (Andaya 1981; Reid 1983; McWilliam et al. 2012). Makassar grew into a cosmopolitan city with an estimated population of up to 100,000 residents (Reid 1993) that was supported by its strategic location between western and eastern Indonesia and its proximity to fertile expanses of land for wet-rice production (Bulbeck 1992). However, between 1667 and 1669, Makassar succumbed to a Dutch naval blockade and overland assault by its Bugis enemies that brought an end to the Makassar Empire. The VOC then took control of Makassar and its international trade, and the Bugis leader and warlord, Arung Palakka, emerged as the apical figure in local politics (Andaya 1981; Bulbeck 1990).

Makassar provides a rare opportunity to understand the emergence of an indigenous empire, made possible by a rich body of Dutch and other European records dating to the 16th and 17th centuries, complemented by indigenous textual sources written in the Makasar language. The most important of the Makasar texts for this study are two "chronicles" and a collection of dated entries referred to as "diaries" or "annals." ${ }^{2}$ The two chronicles focus on Gowa and Talloq, the two Makasar-speaking kingdoms that jointly managed Makassar, and relate the legendary origins of the kingdoms as well as their royal succession before and after their occupation of Makassar (Reid 1983). The major concentration of entries in the diaries date from between circa 1600 and 1754 (Ligtvoet 1880). According to the Gowa chronicle, the first application of writing began during the reign of Tumapaqrisiq Kallonna (1510/1511-1546) and Cummings (2007) argues that a local literary tradition emerged during the reign of Tunijalloq (1565-1590), before the conversion of the Gowa and Talloq aristocracy to Islam in 1605.

An important feature of the Gowa and Talloq chronicles is that they disclose whether information was unavailable and when it derived from 
hearsay, as in their account of the kingdoms' legendary origins and first rulers, which is combined with an attempt to present details when the facts allowed it. The rulers between the late 15 th and middle 17 th centuries are documented in a standard format in the chronicles that include their major achievements, important events during their reign, and record the ruler's known wives and children, often accompanied by information on the children's marriages and offspring. This potential wealth of genealogical information found in the chronicles is expanded by relevant entries in the diaries, especially in sections concerned with the 17 th century that not only present information on noble births, marriages and deaths but include people unrelated to the royalty. However, extracting the genealogical information contained in these texts has been problematic. As Noorduyn (1991) and Cummings (2007) have pointed out, the chronicles have survived in multiple copies that often vary from each other and can be difficult to interpret, even when the extant copies are consulted collectively. The diaries are less problematic but the personages to which they refer had multiple names and the names used in the diaries often differ to those commonly found in other sources (Cummings 2011).

I was confronted with these issues when I first attempted to utilise these chronicles and diaries for my $\mathrm{PhD}$ dissertation on the historical archaeology of Makassar and its environs (Bulbeck 1992; 1996). In addition, I had to rely on the English translations I had made from Indonesian translations of these Makasar texts. In the case of the chronicles, these were Indonesian translations of single extant copies. The recent scholarly Makasar to English translations published by Cummings $(2007 ; 2011)$ thus provide an opportunity to revisit my earlier findings with more reliable and consistent historical data. The findings to be considered here include the roles of descent and marriage in the recognition of status patterns of daughter exchange in relation to Gowa's and Talloq's changing fortunes, and changes in local socio-political organisation with Makassar's expansion and subsequent decline.

\section{MATERIALS AND METHODS}

The primary sources used in the historical analysis presented below are the Gowa and Talloq chronicles and the Makasar diaries, particularly the English translations by Cummings $(2007 ; 2011)$. I also referred to earlier Indonesian translations of these works (Wolhoff and Abdurrahim 1959; Rahim and Ridwan 1975; Kamaruddin et al. 1985/6) in order to clarify points of uncertainty in Cummings' translations. Also utilised were two short Makasar works I included in my original $\mathrm{PhD}$ analysis, "The early history of Sanrabone" and the "The early history of Maros," which are in the form of 
Indonesian translations I made from the original Makasar texts. ${ }^{3}$ Both of these texts elucidate some of the information provided in the major Makasar sources translated by Cummings and I restrict their use to that context only, as my translations have yet to be independently verified.

Important Makasar personages could accumulate numerous names during their life and even after death. Usually, these were in the form of a birth name, a Daeng name (reflecting a person of standing), one or more karaeng lordships (hereafter, karaengships) and a posthumous nickname or a name commemorating the person's burial place. I therefore had to identify in the texts all the name variations recorded for each individual. It is important to keep track of all the components of a person's name as the same person could have different monikers in the different sources used. Accordingly, if the context allowed, I provisionally assumed that any reference to one of the name variations of a person with multiple names was a reference to the one person. This provisional assumption was reversed in known cases of multiple individuals with identical names (see Cummings 2011) or if the assumption led to improbable consequences, such as a woman's name being recorded as a mother outside of usual childbearing years. Also, there are some cases of names that are very common, notably Sitti as a girl's birth name and Luqmuq as a woman slave's title, and so any references to these names were assumed to involve different individuals unless textual evidence to the contrary was found. Such sex-specific names generally allowed the gender of the personages in the texts to be inferred, along with sex-specific designations (e.g., son of X) in the texts, and the sex of recorded marriage partners.

In this study, personages who appear in the chronicles and diaries are assigned to one of six ranks, based on their highest-status recorded name. Rank 1 is reserved for sultans (following conversion to Islam) and personages with posthumous nicknames (such as Tumapaqrisiq Kallona and Tunijalloq, referred to above). Rank 1 also includes personages of non-Makasar ancestry mentioned in the sources, specifically some of the rulers (datu) of three major Bugis kingdoms, Luwuq, Soppeng and Bone, and early sultans of Bima and Sumbawa on Sumbawa Island. Rank 2 is assigned to individual rulers of other independent kingdoms recorded in the sources. These include some of the preIslamic rulers of Talloq, and a wife of an early Talloq king who had the title Karaengloe (great lord/lady). Rank 3 contains many local lords: the Makasar karaeng, and their Bugis and Sumbawa equivalents. Some are from several polities which vacillated between independent rule and subjugated lordship depending on whether or not they had become incorporated within one of the major kingdoms (Bulbeck 1992). Rank 4 was assigned to those who had the title of Gallarrang and Kare, which indicates they were heads of local communities (Cummings 2007). Rank 5 is applied to those personages for 
which there is evidence of them obtaining a status above the ordinary commoner, such as those with daeng and nyai titles, the title Haji for men who had made the pilgrimage to Mecca and, in one case, the commemorated burial place of an otherwise untitled woman. Rank 6 includes untitled persons and persons with slave titles.

To study the genealogical data, I prepared an Excel spreadsheet of 736 persons. ${ }^{4}$ All persons were tagged with a unique acronym that included their rank (1 to 6) or, in the case of unknown persons mentioned in the records, a serial "UK" number (UK001 to UK052). Fathers and mothers, where known, were recorded by their acronyms, as were spouses. In addition, the frequent divorces, which generally preceded a woman's remarriage (polygamy was commonplace, particularly amongst the Rank 1 males) were recorded as notes to the spreadsheet. Recorded marriages were assigned to three periods, following Bulbeck (1996): the late 15th century to circa 1593 (Period 1), 1593 to 1667 (Period 2) and 1667-1700 (Period 3). Dates of birth and death were also entered in order to help tease out the various relationships by marriage and descent.

The archaeological data used here is mainly derived from my detailed and intensive historical archaeological survey conducted in 1986, the methodology for which is set out in Bulbeck (1992). The initial focus of this survey was to relate the 16th and 17th century place names mentioned in the historical sources (mentioned above) to archaeological sites. As fieldwork progressed, I recognised the need to place the historical place names in their archaeological context by recording the additional sites between them. Apart from the remnant fortifications, habitation remains were difficult to trace and date, and so my team focused on mortuary sites, either Islamic cemeteries with 17 th century grave markers or pre-Islamic burial grounds looted for their 13 th/14th to 16 th/17th century imported ceramics.

\section{RESULTS: GENEALOGICAL RELATIONSHIPS AND STATUS}

Tables 1 to 8 respectively present the status relationship between fathers and sons, fathers and daughters, mothers and sons, mothers and daughters, full brothers including those higher/equally ranked, full sisters including those higher/equally ranked, full brothers and sisters, and husbands and wives. In every comparison, one or more of the ranks are represented by a small sample size for at least one of the entities being compared. Accordingly, while the general pattern of the status relationships is visually apparent from the tables, aggregation of ranks into two-by-two tables is required to allow statistical testing. The appropriate statistical test is the two-by-two Chi-square test, 
which can be applied as long as the "expected frequency" in every cell is at least 5. The two-by-two Chi-square statistic can also be used to calculate the Phi-square statistic, which varies between 0 for no relationship, and 1 for a perfect relationship, between the compared entities. With some of the tables, more than one option to aggregate categories would have allowed application of a two-by-two Chi-square test, and in these cases the aggregation that produced the highest Phi-square statistic was chosen. Boxes around the cells in Tables 1 to 8 show how the categories were aggregated for the purposes of statistical testing.

Table 1: Father and son ranks compared.

\begin{tabular}{c|cc|cccc|c}
\hline \multirow{2}{*}{$\begin{array}{c}\text { Son's } \\
\text { rank }\end{array}$} & \multicolumn{7}{|c}{ Father's rank } \\
\cline { 2 - 8 } & 1 & 2 & 3 & 4 & 5 & 6 & Total \\
\hline 1 & 30 & 3 & 1 & - & - & - & 34 \\
2 & 4 & 5 & 1 & - & - & - & 10 \\
\hline 3 & 31 & 8 & 48 & - & 2 & - & 89 \\
4 & - & - & 1 & - & - & - & 1 \\
5 & 13 & - & 16 & - & 2 & - & 31 \\
6 & 7 & 3 & 14 & 2 & 1 & 2 & 29 \\
\hline Total & 85 & 19 & 81 & 2 & 5 & 2 & 194 \\
\hline
\end{tabular}

Chi-square $=40.1(p<0.00001)$, Phi-square $=0.207$.

Table 2: Father and daughter ranks compared.

\begin{tabular}{c|cc|cccc|c}
\hline \multirow{2}{*}{$\begin{array}{c}\text { Daughter's } \\
\text { rank }\end{array}$} & \multicolumn{7}{|c}{ Father's rank } \\
\cline { 2 - 8 } & 1 & 2 & 3 & 4 & 5 & 6 & Total \\
\hline 1 & 1 & - & - & - & - & - & 1 \\
2 & - & 4 & - & - & - & - & 4 \\
3 & 40 & 8 & 10 & - & - & - & 58 \\
\hline 4 & 4 & - & 1 & 5 & - & - & 10 \\
5 & 13 & 3 & 16 & 1 & 1 & - & 34 \\
6 & 12 & 2 & 15 & - & 3 & 1 & 33 \\
\hline Total & 70 & 17 & 42 & 6 & 4 & 1 & 140 \\
\hline
\end{tabular}

Chi-square $=23.5(p<0.0001)$, Phi-square $=0.168$ 
Table 3: Mother and son ranks compared.

\begin{tabular}{c|ccc|ccc|c}
\hline \multirow{2}{*}{$\begin{array}{c}\text { Son's } \\
\text { rank }\end{array}$} & \multicolumn{7}{|c}{ Mother's rank } \\
\cline { 2 - 9 } & 1 & 2 & 3 & 4 & 5 & 6 & Total \\
\hline 1 & 2 & 4 & 13 & 1 & 3 & 3 & 26 \\
2 & 1 & - & 3 & - & 2 & 1 & 7 \\
\cline { 2 - 9 } 3 & 2 & 2 & 22 & 7 & 15 & 13 & 61 \\
4 & - & - & 2 & - & - & - & 2 \\
5 & 1 & - & 7 & - & 6 & 11 & 25 \\
6 & - & 1 & 7 & 1 & 4 & 8 & 21 \\
\hline Total & 6 & 7 & 54 & 9 & 30 & 36 & 142 \\
\hline
\end{tabular}

Chi-square $=8.7(p<0.005)$, Phi-square $=0.062$

Table 4: Mother and daughter ranks compared.

\begin{tabular}{c|ccc|ccc|c}
\hline \multirow{2}{*}{$\begin{array}{c}\text { Daughter's } \\
\text { rank }\end{array}$} & \multicolumn{7}{|c}{ Mother's rank } \\
\cline { 2 - 8 } & 1 & 2 & 3 & 4 & 5 & 6 & Total \\
\hline 1 & - & - & 1 & - & - & - & 1 \\
2 & - & 3 & - & - & - & - & 3 \\
3 & - & - & 30 & 3 & 9 & 5 & 47 \\
\hline 4 & - & - & - & 1 & 1 & 4 & 6 \\
5 & - & - & 4 & 3 & 3 & 5 & 15 \\
6 & 1 & - & 15 & 3 & 9 & 11 & 39 \\
\hline Total & 1 & 3 & 50 & 10 & 22 & 25 & 111 \\
\hline
\end{tabular}

Chi-square $=12.3(p<0.001)$, Phi-square $=0.110$

Table 5: Full brother ranks compared.

\begin{tabular}{c|cc|cccc|c}
\hline \multirow{2}{*}{$\begin{array}{l}\text { Other } \\
\text { brother's rank }\end{array}$} & \multicolumn{7}{|c}{ Higher/equal ranked brother's rank } \\
\cline { 2 - 8 } & 1 & 2 & 3 & 4 & 5 & 6 & Total \\
\hline 1 & 7 & - & - & - & - & - & 7 \\
2 & 3 & - & - & - & - & - & 3 \\
3 & 13 & 6 & 19 & - & - & - & 38 \\
\hline 4 & - & - & - & - & - & - & 0 \\
5 & 4 & 1 & 9 & - & 3 & - & 17 \\
6 & - & 1 & 6 & - & 2 & 2 & 11 \\
\hline Total & 27 & 8 & 34 & 0 & 5 & 2 & 76 \\
\hline
\end{tabular}

Chi-square $=5.6(p<0.025)$, Phi-square $=0.084$ (Note: other brothers of Rank 1 and 2 excluded from statistical testing, to avoid the bias of the necessarily Rank 1 or 2 status of their higher or equally ranked brother) 
Table 6: Full sister ranks compared.

\begin{tabular}{c|c|c|c|c|c|c|c}
\hline \multirow{2}{*}{$\begin{array}{c}\text { Other sister's } \\
\text { rank }\end{array}$} & \multicolumn{7}{|c}{ Higher/equal ranked sister's rank } \\
\cline { 2 - 8 } & 1 & 2 & 3 & 4 & 5 & 6 & Total \\
\hline 1 & - & - & - & - & - & - & 0 \\
2 & - & - & - & - & - & - & 0 \\
3 & - & 1 & 16 & - & - & - & 17 \\
\hline 4 & - & - & - & 1 & - & - & 1 \\
5 & - & - & 5 & 4 & 2 & - & 11 \\
\hline 6 & 2 & - & 8 & 2 & 5 & 3 & 20 \\
\hline Total & 2 & 1 & 29 & 7 & 7 & 3 & 49 \\
\hline
\end{tabular}

Chi-square $=0.2$ (not significant), Phi-square $=0.006$ (Note: other sisters of Rank 1 to 3 excluded from statistical testing, to avoid the bias of the necessarily Rank 1 to 3 status of their higher or equally ranked sister)

Table 7: Full brother and sister ranks compared.

\begin{tabular}{c|cc|cccc|c}
\hline \multirow{2}{*}{$\begin{array}{c}\text { Sister's } \\
\text { rank }\end{array}$} & \multicolumn{7}{|c}{ Brother's rank } \\
\cline { 2 - 8 } & 1 & 2 & 3 & 4 & 5 & 6 & Total \\
\hline 1 & - & - & - & - & - & - & 0 \\
2 & 1 & - & - & - & - & - & 1 \\
3 & 29 & 4 & 24 & - & 11 & 5 & 73 \\
\hline 4 & 1 & - & 4 & - & 1 & - & 6 \\
5 & 1 & - & 12 & - & 4 & - & 17 \\
6 & 5 & 4 & 14 & - & 2 & 2 & 27 \\
\hline Total & 37 & 8 & 54 & 0 & 18 & 7 & 124 \\
\hline
\end{tabular}

Chi-square $=7.4(p<0.01)$, Phi-square $=0.060$

Table 8: Husband and wife ranks compared.

\begin{tabular}{c|ccc|ccc|c}
\hline \multirow{2}{*}{$\begin{array}{c}\text { Wife's } \\
\text { rank }\end{array}$} & \multicolumn{7}{|c}{ Husband's rank } \\
\cline { 2 - 8 } & 1 & 2 & 3 & 4 & 5 & 6 & Total \\
\hline 1 & 1 & - & - & - & - & - & 1 \\
2 & 4 & - & 1 & - & - & & 5 \\
3 & 38 & 10 & 45 & - & 4 & - & 97 \\
\hline 4 & 9 & 3 & 8 & 2 & 3 & 1 & 26 \\
5 & 25 & 6 & 45 & 1 & 14 & 3 & 94 \\
6 & 28 & 1 & 26 & 3 & 10 & 7 & 75 \\
\hline Total & 105 & 20 & 125 & 6 & 31 & 11 & 298 \\
\hline
\end{tabular}

Chi-square $=17.4(p<0.0001)$, Phi-square $=0.058$ 
Table 1 and Table 2 indicate that a father's rank set a ceiling on the rank of his daughters and, to a large degree the rank of any son's. Indeed, the strongest correlations to emerge from any of the comparisons as measured by the Phisquare results are those between a father's rank and his offspring of either gender. The father-son comparison shows that a male had very little chance of becoming a ruler unless he was the son of a ruling male. The father-daughter comparison additionally shows that even a daughter of a ruling male had little chance of becoming a ruler herself, although she did have considerably more chance of becoming a karaeng than daughters of males who were not a ruler. However, as the main focus of the historical sources is the offspring of rulers, they give little attention to the offspring of males of lower rank than karaeng. Therefore, there is a possibility that the children of lowly ranked males had more opportunity to rise above their father's status than indicated in Table 1 and Table 2.5

Table 3 shows a positive correlation of moderate strength between a mother's and a son's rank; specifically, aristocratic mothers (Ranks 1 to 3) were more likely to have sons who became rulers than non-aristocratic mothers. However, the proportion of aristocratic women who married rulers $(53 / 103)$ was higher than the proportion of non-aristocratic women who married rulers (72/195; see Table 8), thus the strength of the father-son status relationship may be sufficient to explain the mother-son status relationship. This is not, however, the case with the mother-daughter status relationship (Table 4) whereby the likelihood of aristocratic mothers having aristocratic daughters considerably exceeded that of non-aristocratic mothers. Accordingly, there is a case for recognising that the aristocratic status of a woman was passed on to her daughters independently of her husband's status. Results show that full sibling status relationships were variable. A brother's rank as a ruler was positively correlated with the status of his sister, and the status of any lower or equally ranked brother, as an aristocrat (Table 5 and Table 7). On the other hand, there is minimal indication that a sister's aristocratic status had a bearing on the aristocratic or other status of any lower or equally ranked sister (Table 6). What this may suggest is that full siblings of male rulers enjoyed improved prospects for advancing their status by virtue of their direct relationship to the ruler.

In all of these comparisons, it can be seen that males dominated Ranks 1 and 2, while females are more strongly represented than males in Ranks 4 to 6. Both genders were fairly equally represented at the karaeng level of Rank 3. This male domination of ruling positions appears to have formed the basis for their sons to have the chance to succeed as rulers and for their daughters, and equally or lower ranked siblings (male or female), to have risen to the 
status of aristocrats. Males also dominated Makassar's administrative posts, as will be shown in the next section.

\section{RESULTS: MAJOR MAKASSAR PATRILINES AND THEIR GEOGRAPHIC EXTENT}

The preceding analysis of familiar status relationships shows that the kinship system in the upper echelons of Makassar society was essentially patrilineal. With very few exceptions, men who were sons of a previous ruler were the only ones who had a realistic chance of becoming a ruler. Indeed, one of the few exceptions is particularly illustrative of this pattern as it involved a Talloq queen (daughter of the king she succeeded) who married a Gowa king. This led to the Talloq throne being inherited by their son and the threat that rule over Talloq would then pass patrilineally along the son's line (see Figure 2 and related discussion). In addition, a woman's probability of attaining the status of a karaeng was greatly increased if she was the daughter of a previous male ruler (Table 2).

The karaeng titles, whether these were the highest title attained by an individual or a title that was preliminary to ruling a kingdom, are highly informative. This is because most of these karaeng titles link the individual to a specific location. This locational information allows us to document, over time, the spatial extent of the influence of Makassar's major patrilines. Most of these locations are documented in Bulbeck (1992) and several additional locations (Bontolangkasak and Bontomangape in present-day Makassar city, Majannang in southern Maros and Bontomajannang on the south coast) were identified more recently as preparation for the present study. Unfortunately, a few of the karaengship locations cannot be identified with complete confidence, such as Loaya, Katapang and Ballaq (Figure 1).

Figure 1 presents an example of Tuniawanga's male descendants. He is the seventh recorded Gowa ruler but the first ruler for whom the sources give detailed information on descendants. Throughout the 16th and 17th centuries, the karaengship locations of his male descendants were concentrated in Kale Gowa, which was Gowa's centre. ${ }^{6}$ Around Kale Gowa, along the lower reaches of the Jeqneqberang River and extending into present-day Makassar city, on the cusp of the 16th century there was a halo of dense karaengship locations, including Garassiq. In addition, there were also several far-flung karaengship locations, such as Maros and Patteqne to the north of Makassar in the early 16th century, and Jeqneqponto and Bontomajannang on the south coast in the 17 th century. 
A proportion of Tuniawanga's male descendants (as shown on the left half of Figure 1) also recorded marital relationships with other important Makassar lineages. ${ }^{7}$ These marital relationships are recorded for all of Tuniawanga's royal sons, from Tumapaqrisiq Kallona (1510/1511-1546) to Sultan Abdul Jalil (1667-1709), with the exception of Tunipasuluq (15901593) who was expelled from Gowa in 1593 while still in his teens. These marital relationships can be grouped together in documenting Gowa's royal marital relationships for the three periods: circa 1500-1593 (the year of the palace revolution that led to the expulsion of Tunipasuluq), circa 1593-1667 (the year of the abdication of Sultan Hasanuddin, following the occupation of Makassar by the VOC), and circa 1667-1700 (the end date of this study, shortly before the death of Abdul Jalil, the last patrilineal royal descendant of Tuniawanga). In addition, the sources also record other marital relationships between other important Makassar lineages and the patrilineal descendants of Tuniawanga who did not become ruler, but this is to a maximum genealogical depth of two generations. These relationships can be grouped together under the "Gowa nobility" category for the circa 1500-1593, 1593-1667 and 16671700 periods.

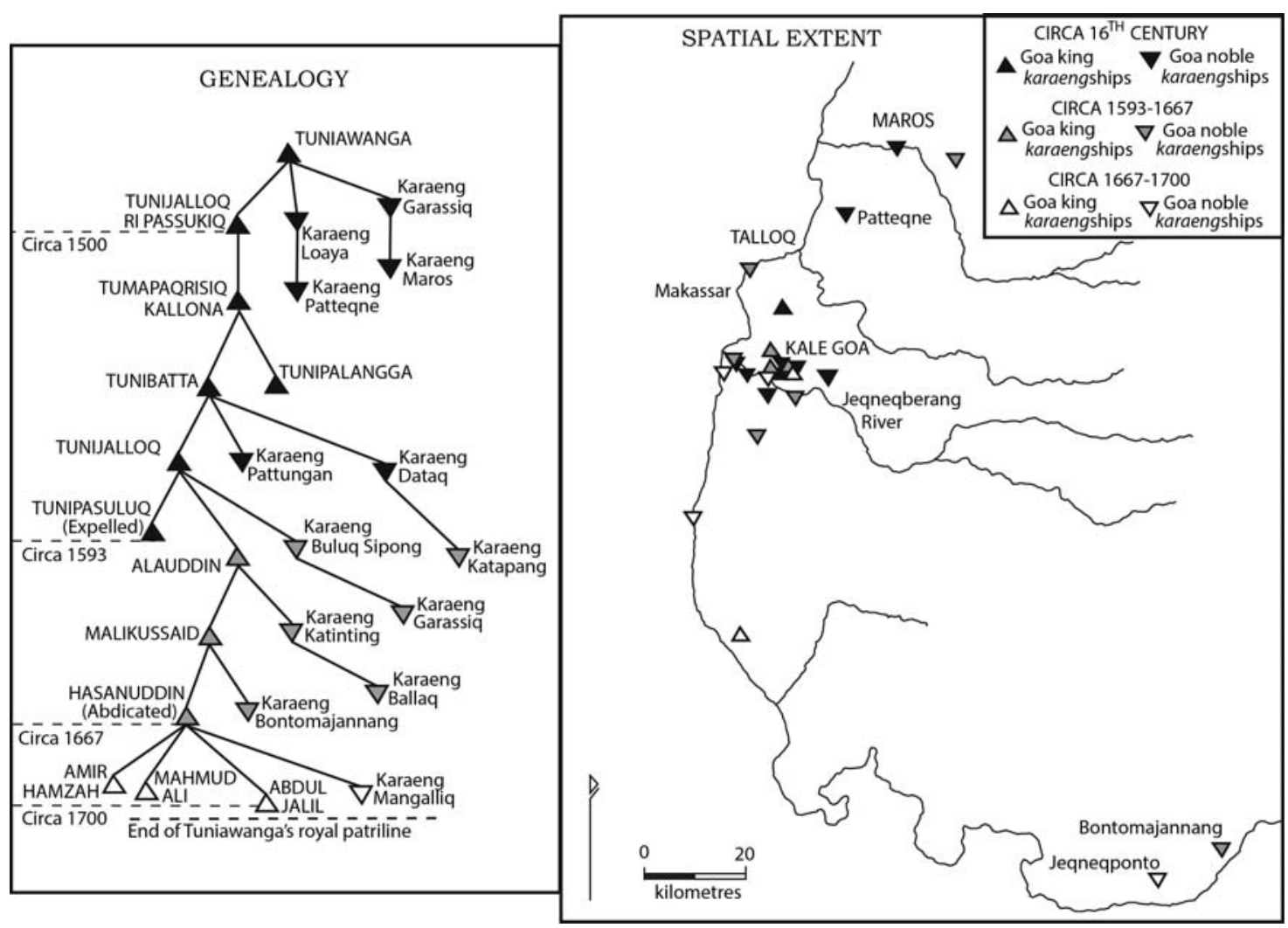

Figure 1: Gowa royalty and significant nobility, Tuniawanga's patriline. 
Figure 2 shows how the locations of the Talloq karaengship titles overlapped extensively with those of Gowa. There are, however, three noteworthy distinctions. The first is that one focus of Talloq's locations is the Talloq fortress and adjoining southern border of the Sungai (river) Talloq's estuarine stretch, an area free of Gowa-related karaengships. Second, no Talloq karaengships were located inside Kale Gowa until the Kaballokang karaengship toward the end of the 17th century. Third, while the furthest outlying Talloq and Gowa karaengship were a similar distance from Makassar, those of Talloq lay to the north (Segeri) rather than to the southeast, as was the case with Gowa.

The genealogy of the descendants of Karaengloe ri Sero, the founder of the Talloq dynasty, reveals three main aspects that are of particular interest (Figure 2). First, the administrative position of Tumibicara-butta ("speaker of the land") was initiated in the 16th century and first held by the Talloq king, Tumenanga ri Makkoayang. Subsequently, his patrilineal descendants almost exclusively occupied the position, although not all were kings. Second, rulership of Talloq was transmitted from Tumenanga ri Makkoayang to his daughter, Karaeng Bainea ("the female karaeng"), who was married to the then king of Gowa, Tunijalloq. Rulership over Talloq was then transmitted to their son, Tunipasuluq. After Tunipasuluq was expelled during the palace revolution he was replaced by another son of Tumenanga ri Makkoayang called Sultan Abdullah (after conversion to Islam in 1605), which reestablished rule over Talloq as the prerogative of the patrilineal descendants of Karaengloe ri Sero. Third, one of the sons of Sultan Abdullah, called Karaeng Popoq, occupied the Tumakkajannang ("crafts master") position, which was later passed onto Karaeng Popoq's son, Karaeng Bontomanompo. Thus, both the Talloq royal and noble patrilines included persons who occupied important administrative positions, which contrasts with Gowa royal and noble patrilines that did not. 


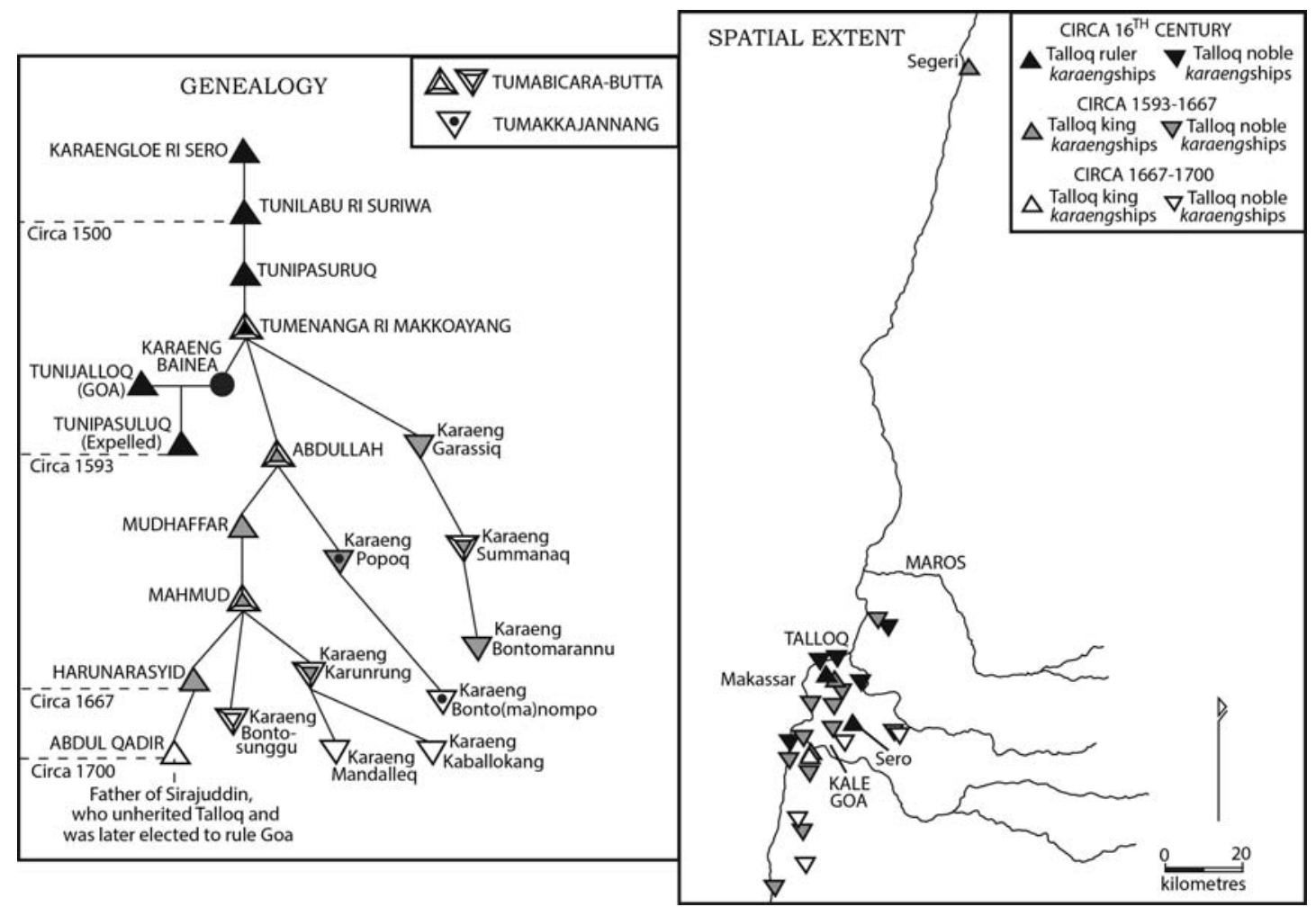

Figure 2: Talloq royalty and significant nobility.

In addition to Gowa and Talloq, the third major Makassar lineage included the Maros rulers and their descendants. In the early 16th century, Maros temporarily became a karaengship of Gowa (Figure 1) but in the mid-16th century established an independent Maros ruling patriline (Figure 3). At some point during his reign over Goa (1565-1590), Tunijalloq promised the Maros ruler that his descendants would be appointed to one of the Tumailalang ("minister of internal affairs") posts as long as Tunijalloq's descendants ruled over Goa. The first from Maros appointed was I Yunyiq Karaeng Maros (Cummings 2007). According to "The early history of Maros," Tunipasuluq briefly became the ruler of Maros before his expulsion (Bulbeck 1992) and the Gowa chronicle informs that Tunipasuluq also replaced Daeng ri Tamacinna with Karaeng ri Patteqne as the Tumailalang post holder (Cummings 2007). Thereafter, the descendants of both Karaeng ri Patteqne and especially I Yunyiq, occupied one of the streams of the Tumailalang post, and even the position of Tumibicara-butta towards the end of the 17th century (see Figure 3). Spatially, the karaengships concerned lay to the north of Makassar during the 16th century, but shifted southwards during the 17th century to overlap with the spatial extent of the Gowa and Talloq karaengships. 


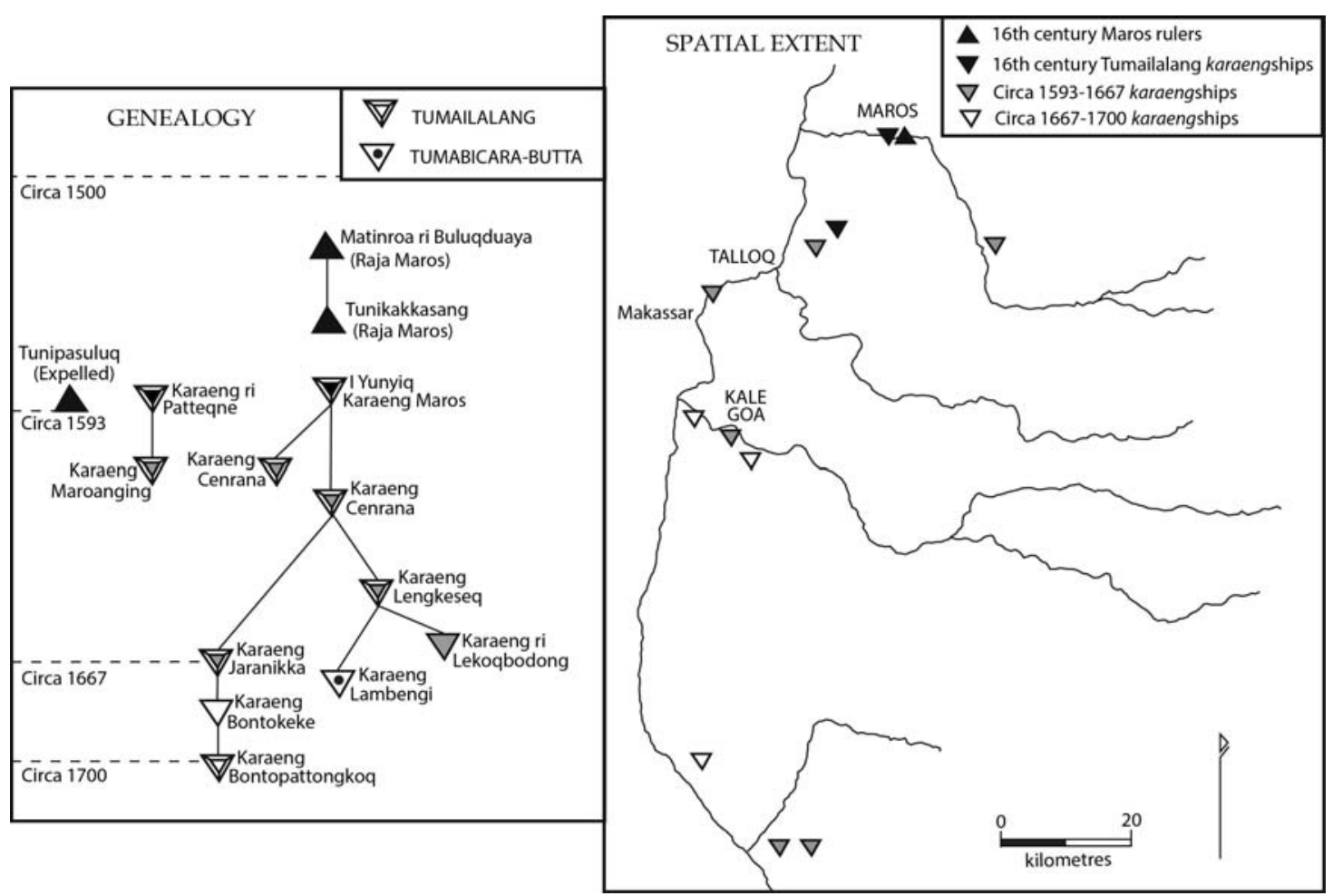

Figure 3: Maros royalty and significant nobility.

\section{RESULTS: SHIFTING PATTERNS OF MARITAL ALLIANCES OVER TIME}

The marital relationships of the major Makassar and related patrilines during the period circa 1500-1593 are shown in Figure 4. These relationships are shown in terms of the movement of wives from the patriline of their fathers to the patriline of their husbands, in accord with the essentially patrilineal kinship system of elite Makassar society. Three main points emerge that are particularly relevant to understanding the 16th century political history of the polities in the vicinity of Makassar.

The first point is the role of Gowa as an absorber rather than a giver of daughters in marital exchange. There were two instances of Gowa kings marrying their niece, both daughters of a previous Gowa king. Excluding these quasi-incestuous marriages, there are just eight recorded cases of Gowa king's daughters being married to socio-politically identifiable men, two of whom married Gowa nobles. In comparison, there are 12 recorded cases of the female offspring of these marriages (daughters of Gowa rulers with sociopolitically identifiable men) marrying a Gowa king. What is evident is that Gowa's rise to local prominence, which led to Tunipasuluq temporarily occupying the Talloq and Maros thrones as well as that of Gowa, correlates 
with a predominant movement of daughters for marriage into, rather than out of, Gowa. The main providers of these daughters were Talloq (six) and Polombangkeng (four).

The second point is illustrated by the data from Polombangkeng, where the pattern is opposite to that for Gowa: one of fragmentation. In the mid-16th century Polombangkeng was a powerful coalition of seven kingdoms to the south of Gowa, extending from Jamarang in the north to Lengkeseq in the south. Before several of the Polombangkeng polities were incorporated as karaengships into the major Makassar lineages, three of its more northerly polities provided six daughters in marriage for Gowa and others in the vicinity of Makassar. The only Polombangkeng polity recorded as receiving a daughter from Gowa (a ruler's daughter) is Sanrabone, which continued as an important kingdom into the 17th century (Bulbeck 1992; 1996).

The third main point is the strongly localised scope of recorded marital relationships before 1593. Indeed, there is just one long-distance relationship recorded in the 16th century. This was between a daughter of the Gowa king Tunipalanga and the ruler of the Bugis kingdom of Massepeq that took place in the mid-16th century (Figure 4).

The geographic scope of Makassar's recorded marital relationships expanded considerably during circa 1593-1667, although the majority (39 out of 49) remained local in scope (Figure 5). The increased geographical scope of these marital relationships included four marriages involving the Bima Sultanate, two involving the Sumbawa Sultanate, and three that involved the Bugis sultanates of Luwuq, Soppeng and Bulo-Bulo. In addition, a daughter of Talloq's Sultan Mudhaffar married Kaicili Kalamata, the brother of Ternate's Sultan Mandar Syah, although this was not strictly long-distance as Kaicili Kalamata was resident in Makassar and became a military commander in the failed defence of the city against the VOC and Bugis (Andaya 1981).

Within the vicinity of Makassar, movements of daughters in these marital exchanges were considerably more reciprocal in character circa 15931667 compared to the 16th century. For example, 13 daughters from identifiable local patrilines married a Gowa king, while 13 daughters of Gowa kings also married into identifiable local patrilines, albeit four to Gowa nobles. The exchange of princesses (the daughters of rulers) between Gowa and Talloq remained strong during this period 1593-1667 but the Tumailalang (Maros) patriline also emerged as a third local focus of marital relationships (Figure 5, left half). 


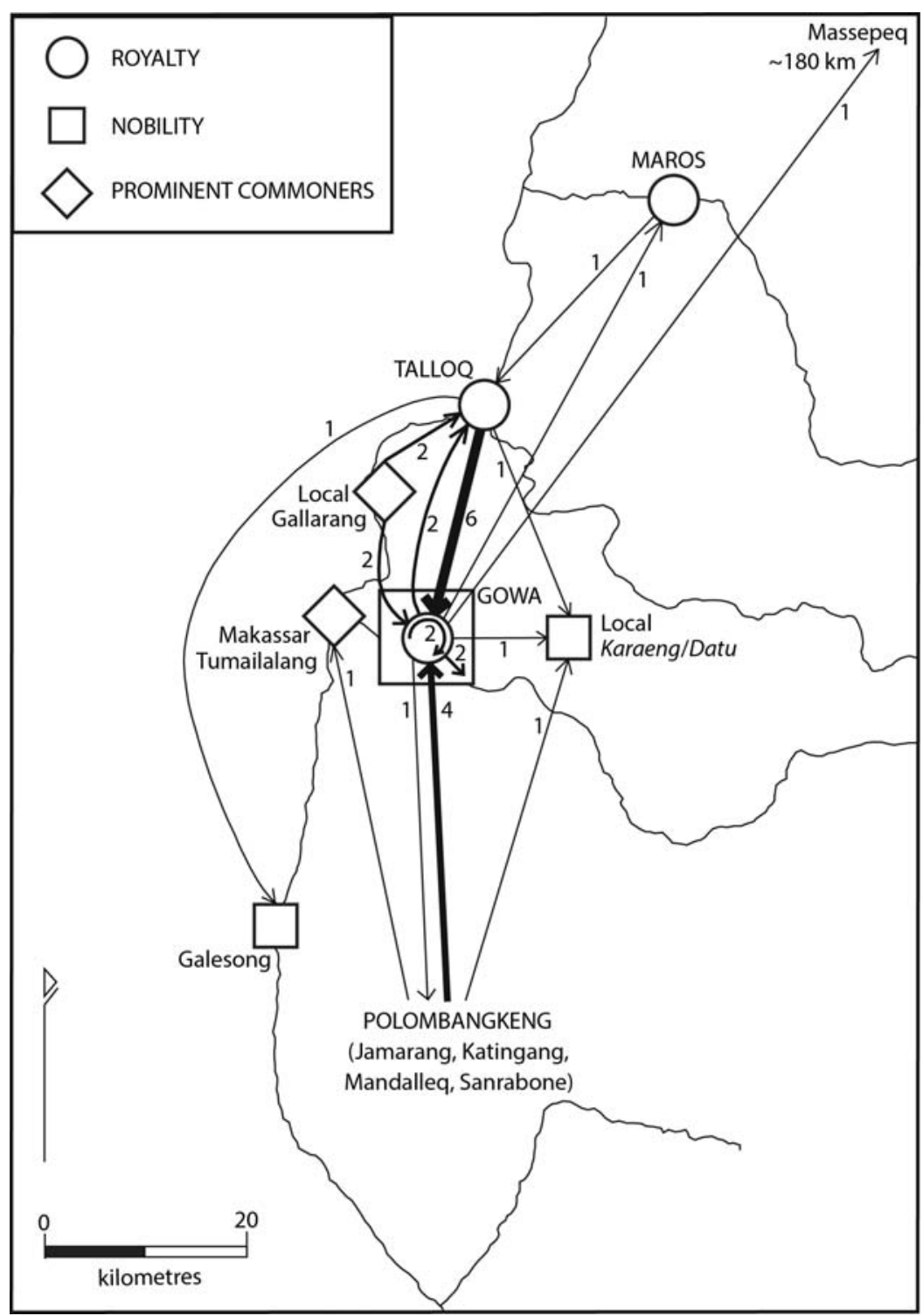

Figure 4: Circa 16th century (to 1593) daughter marital movements.

A major change can be detected between circa 1667 and 1700 as the recorded marriage relationships are notably marked by a major exodus of daughters from the Makassar patrilines as they married into surrounding polities. There are 16 daughters recorded as marrying Bugis rulers and nobles, three daughters with the Sumbawa and Bima Sultanates and one in Barus, Kalimantan. Furthermore, there are no recorded marriages of daughters from the surrounding Makasar polities into the Makassar patrilines during this period (Figure 6). It is of course, these years that mark the Makasars' loss of control over the city of Makassar to the VOC and the Bugis kingdom of Bone, the latter of which became a major recipient of daughters from the Makassar patrilines during this period. To some degree, this picture of an exodus of marriageable daughters out of Makassar is partly exaggerated by their 
frequent remarriages, such as Karaeng Langelok, a daughter of Sultan Hasanuddin, being involved in six of the marriages shown in Figure 6. However, even this can be interpreted as a faltering attempt by the traditional Makassar patrilines to create critical alliances as their control over Makassar began to fade into memory.

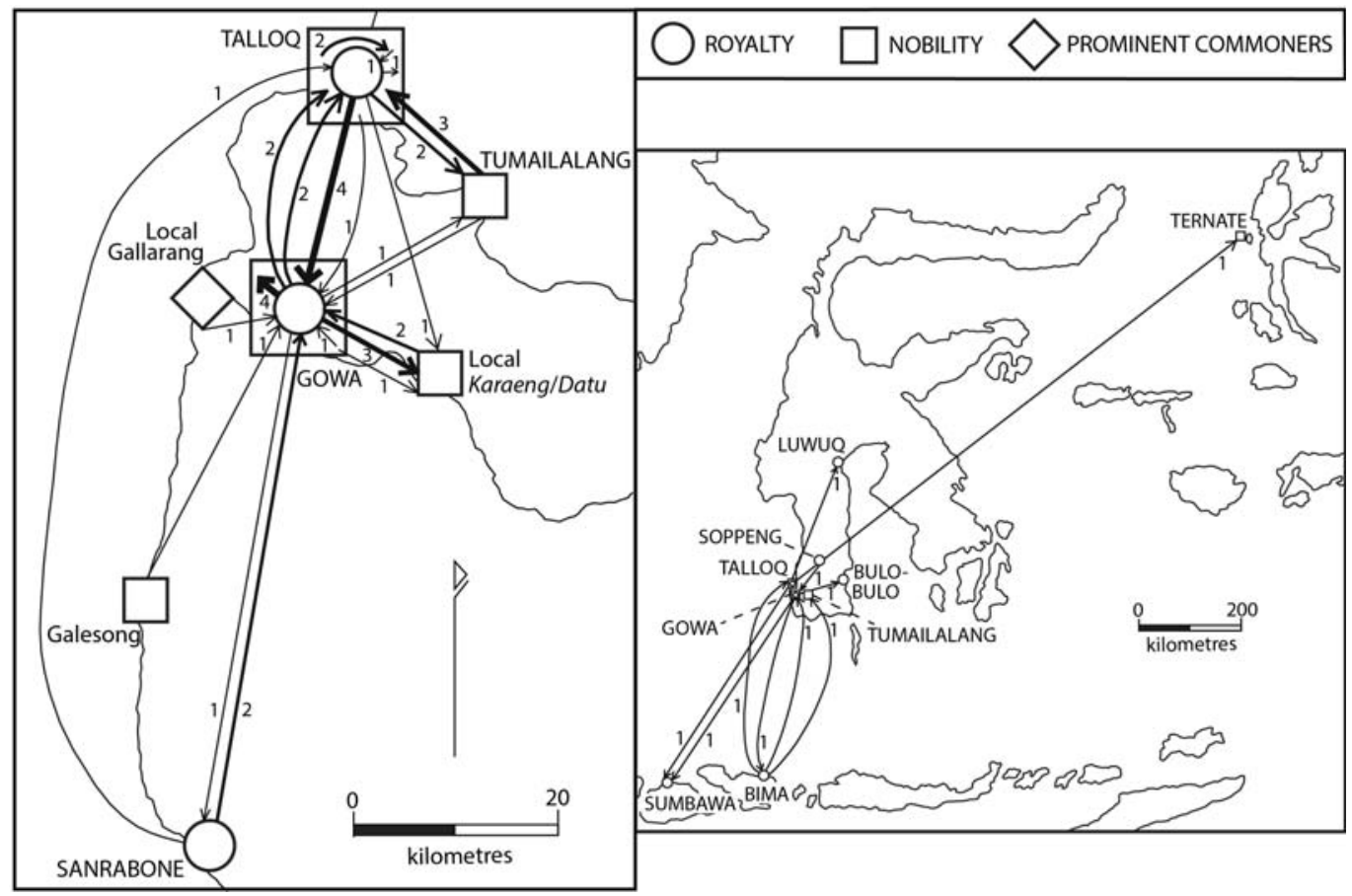

Figure 5: Circa 1593 to 1667 daughter marital movements.

Marital relationships recorded within the vicinity of Makassar itself circa 1667-1700 decreased significantly in comparison to earlier periods but do nevertheless reveal one important point: for the first time, there was considerably less marital movement of daughters into the Gowa aristocracy (three) than out of the Gowa aristocracy (12) (Figure 6, left half). Half of these daughters (six) married Talloq aristocrats, which paved the way for the early 18th century occupancy of the Gowa throne by the Talloq Sultan Sirajuddin (see Patunru 1983). 


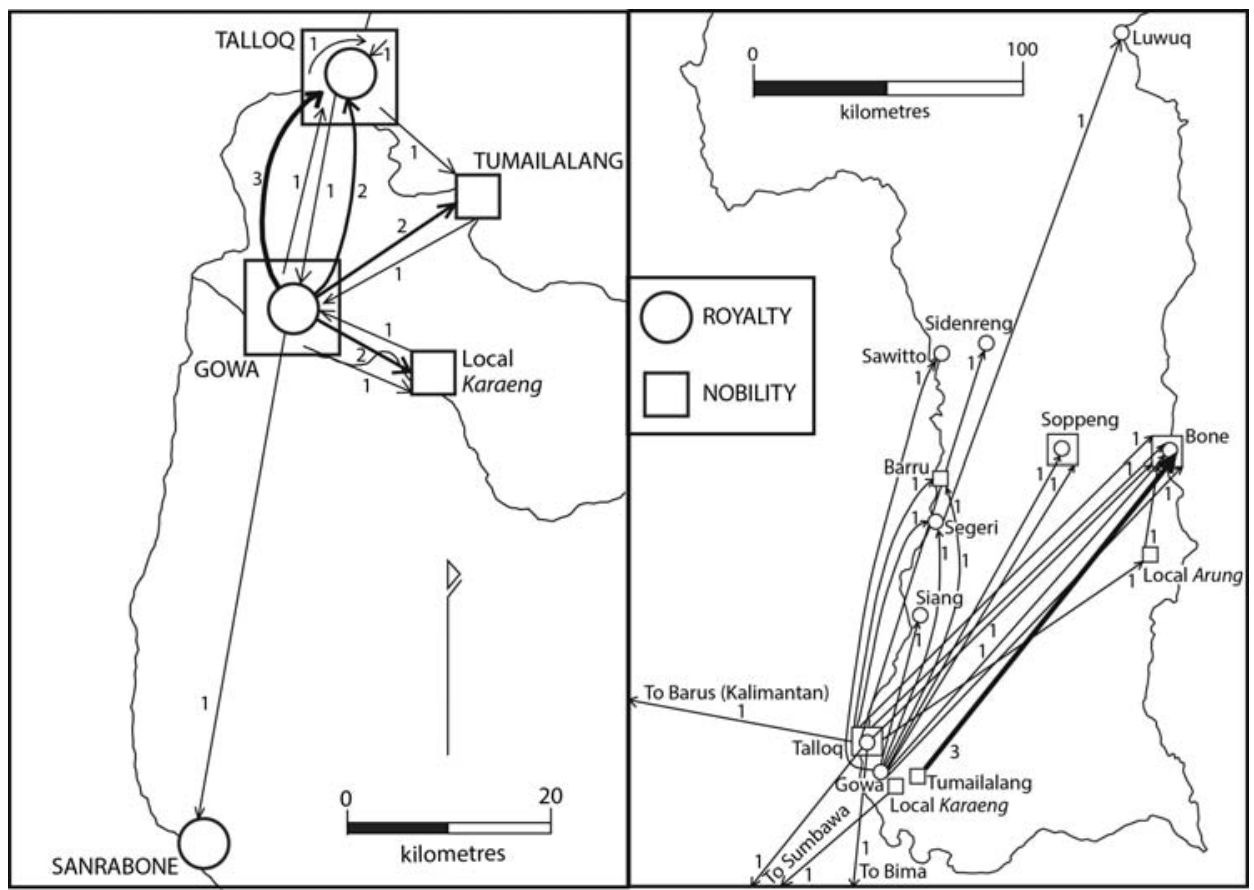

Figure 6: Circa 1667 to 1700 daughter marital movements.

\section{RESULTS: SETTLEMENT PATTERNS IN THE VICINITY OF MAKASSAR OVER TIME}

The final set of results to consider here focuses on reconstructible settlement patterns in Makassar and its environs between the early 16th and middle 17th centuries. The crucial data for this derives from my intensive and detailed site survey across the areas outlined in Figures 7 and 8 (Bulbeck 1992). This is supplemented by later geographically disconnected surveys of the Talloq and Sanrabone fortresses ${ }^{8}$ and information for other inhabited locations near the surveyed area, particularly in present-day Makassar city, as documented in Bulbeck (1992). These locations include toponyms that appear in both the historical sources and records compiled prior to any of my surveys by the local heritage service (Suaka Peninggalan Sejarah dan Purbakala Sulawesi Selatan), which are of celebrated Islamic tombs. ${ }^{9}$

Four time slices that correspond to the early and middle 16th century and the early and middle 17th century, are mapped to sites in Figures 7 and 8. Table 9 explains how the surface finds from these surveyed sites are dated to these four time slices. The sites themselves (toponymic locations) may have been continuously occupied during most, or all, of the period considered here but are shown only for the time slice(s) when they can be related to one of the three major Makassar patrilines. This is to allow for a presentation of the approximate zones of Gowa and Talloq influence over time, which is 
supported by information on the Gowa and Talloq karaengships locations (Figures 1 and 2) within the intensively surveyed area.

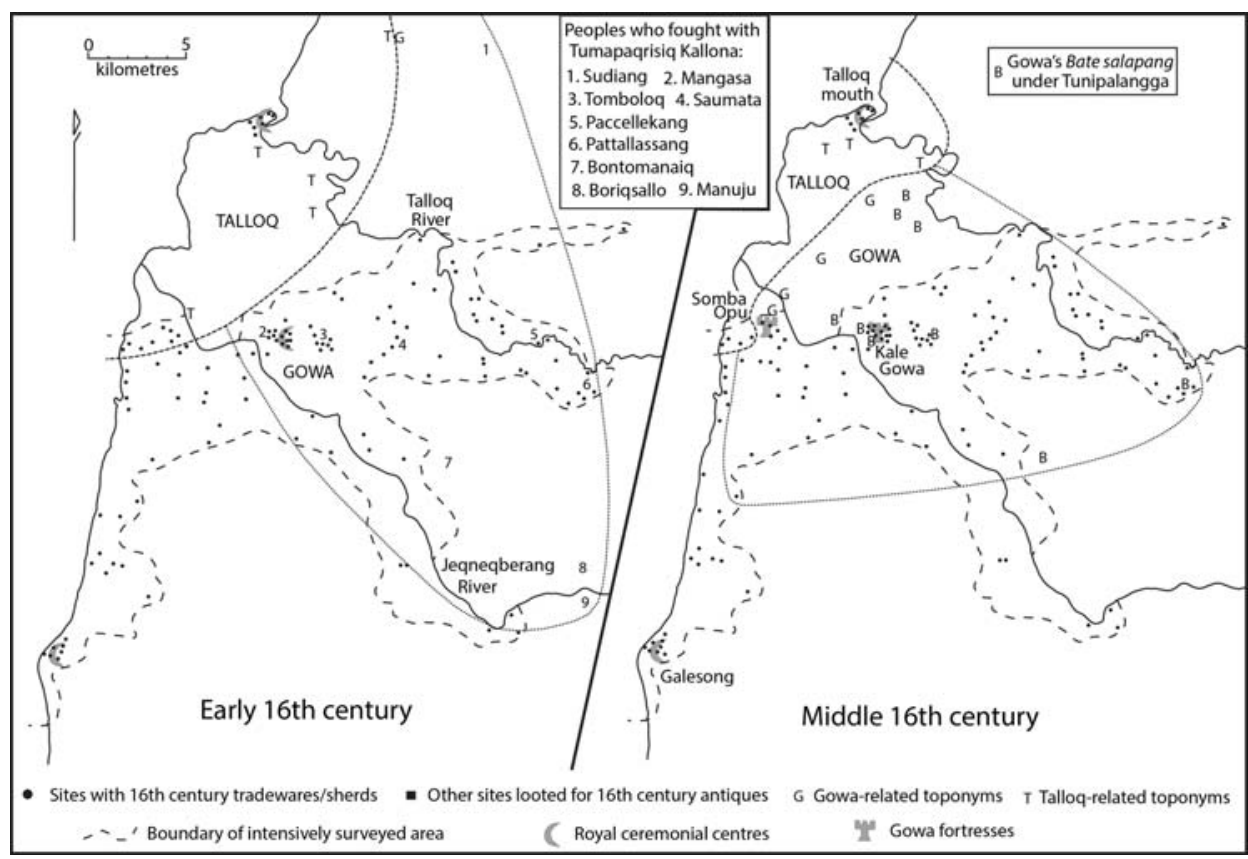

Figure 7: Sixteenth century geographic information for Makassar and its environs.

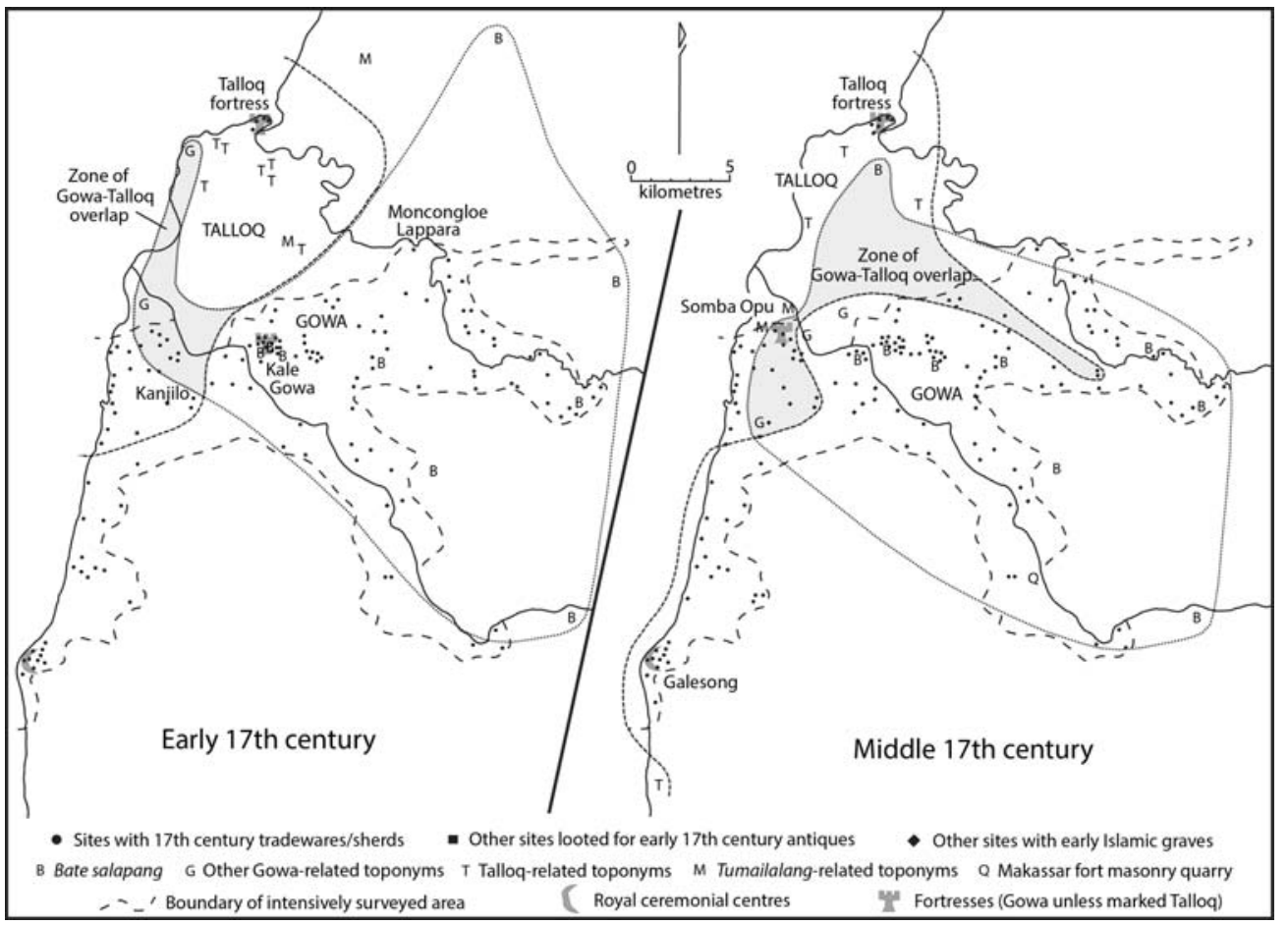

Figure 8: Seventeenth century geographic information for Makassar and its environs. 
Table 9: Surface finds/witnessed local antiques ${ }^{(a)}$ used in dating sites to the four time slices.

\begin{tabular}{|c|c|c|c|c|}
\hline Surface find & $\begin{array}{l}\text { Early } \\
\text { 16th C }\end{array}$ & $\begin{array}{l}\text { Mid } \\
16 \text { th C }\end{array}$ & $\begin{array}{l}\text { Early } \\
17 \text { th C }\end{array}$ & $\begin{array}{l}\text { Mid } \\
17 \text { th C }\end{array}$ \\
\hline Vietnamese blue-and-white/overglaze enamelled & $\sqrt{ }$ & - & - & - \\
\hline Sawankhalok black-and-white & $\sqrt{ }$ & $\sqrt{ }$ & - & - \\
\hline Ming blue-and-white & $\sqrt{ }$ & $\sqrt{ }$ & - & - \\
\hline Ming overglaze enamelled & $\sqrt{ }$ & $\sqrt{ }$ & - & - \\
\hline Ming "Swatow" & $\sqrt{ }$ & $\sqrt{ }$ & - & - \\
\hline Wan-li & - & $\sqrt{ }$ & $\sqrt{ }$ & - \\
\hline Late Ming blue-and-white & - & $\sqrt{ }$ & $\sqrt{ }$ & - \\
\hline "Swatow" & - & - & $\sqrt{ }$ & $\sqrt{ }$ \\
\hline $\begin{array}{l}\text { Large looted areas away from Islamic graveyards } \\
\text { where blue-and-white and black-and-white wares } \\
\text { were reported as the main haul }\end{array}$ & $\sqrt{ }$ & $\sqrt{ }$ & - & - \\
\hline $\begin{array}{l}\text { Small looted areas in remote locations away from } \\
\text { Islamic graveyards with atypical reports on the } \\
\text { haul }\end{array}$ & - & - & $\sqrt{ }$ & $\sqrt{ }$ \\
\hline Looted Islamic cemeteries & - & - & $\sqrt{ }$ & - \\
\hline East-west oriented Islamic graves ${ }^{(b)}$ & - & - & $\sqrt{ }$ & - \\
\hline $\begin{array}{l}\text { Islamic graves of personages deceased in early } \\
17 \text { th century }\end{array}$ & - & - & $\sqrt{ }$ & - \\
\hline Other cemeteries with early Islamic graves ${ }^{(\mathrm{c})}$ & - & - & - & $\sqrt{ }$ \\
\hline
\end{tabular}

(a) Chronological assignments for tradeware classes adapted from Bulbeck (1996-1997: Table 8). (Other, rarer tradeware classes provide no additional information for the present analysis.) Sherds and witnessed antiques used for dating sites in preference to other lines of evidence. Where two adjacent time slices are covered by just one sherd, the latter time slice is employed, except where both time slices are supported by complementary evidence.

(b) The Makasars inhumed their deceased along an east-west orientation between c. 1400 and 1600, and so Islamic graves oriented east-west oriented (rather than with the head directed north and the face turned toward Mecca) reflect a transitional Islamic practice (Bulbeck 1996-1997).

(c) Include cemeteries with the graves of personages who died in the mid-17th century.

The first of three observations to make is how little settlement patterns within the intensively surveyed area appear to have changed between the early 16 th and middle 17th centuries. Most of the recorded sites show continual occupancy throughout this period, especially at the following major site clusters: the Talloq inlet, Somba Opu, Kale Gowa, Tomboloq and Saumata (directly to the east of Kale Gowa), and Galesong. The only detectable suggestions of systematic change involve a faint increase over time in the 
number of sites within 5 kilometres of the coast, and perhaps in the number of sites located close to Kale Gowa.

The second observation to make is the location of the major site clusters, which are strategically situated for an economy based on longdistance trade and supported by local agricultural productivity. The Talloq inlet was a useful safe harbour for ships, and while this saline landscape would not appear particularly promising for agriculture, the Talloq chronicle (Cummings 2007) does remark on efforts made by the second and fourth rulers of the kingdom to increase wet-rice production. Somba Opu lies near the mouth of the Jeqneqberang River. This river not only provided a network of channels for the movement of watercraft but its annual flooding during the monsoon season also created idea conditions for wet-rice cultivation. Kale Gowa and Tomboloq were essentially islands of raised land within a vast sea of fertile wet-rice fields, while Saumata and the other sites to the east of Tomboloq sat at the edges of depressions ideally suited for annual wet-rice farming (Bulbeck 1992). The location of Galesong on a promontory was perhaps the basis of its strategic importance in the local economy, as witnessed by the 30,000 Makassar and allied troops who defended Galesong in 1667 against the combined onslaught of VOC naval forces and Bugis ground troops, who appropriated Galesong's rice harvest as a spoil of victory (Andaya 1981).

The third observation to make is the durability of Gowa's and Talloq's core zones of influence, which abutted each other during the 16th century but overlapped during the 17th. Gowa's core zone continually included the quadrangle of undulating land that was bounded by the middle reaches of the Jeqneqberang River to the southwest and the Talloq River to the northeast, with the four points located approximately at Kale Gowa, Bontomanaiq, Pattallassang and the Moncongloe Lappara site. During the 16th century this core zone appears to have been particularly large, extending as far as Maros to the north of the mapped area. Also included in this zone are nine widely dispersed peoples who are recorded as having fought alongside Tumapqrisiq Kallona (Cummings 2007: 32-33) in battle when the kingdoms of Polombangkeng, Talloq and Maros joined forces against Gowa in the 1530s.

Talloq's core zone continually spanned the mouths of the Jeqneqberang and Talloq rivers. This zone was most reduced during the middle 16th century, when Tunipalangga erected fortresses at Somba Opu as well as Kale Gowa, and Gowa-related toponyms covered the eastern half of present-day Makassar city. Indeed, Gowa effectively absorbed Talloq during the late 16th century, when the Gowa king Tunijalloq (based in Somba Opu) married the Talloq queen Karaeng Bainea and their son, Tunipasuluq, inherited both thrones. This lasted until Karaeng Matoaya (later Sultan Abdullah) led the 
palace revolution that restored the traditional balance of Talloq being the seaward-based partner and Gowa the hinterland-based partner. Geopolitical conformation of the re-establishment of this relationship is seen in the development of an overlapping zone between Gowa and Talloq during the 17 th century (Figure 8).

\section{CONCLUSION}

Intensive survey of historical archaeological sites crucially complements analysis of the Makasar historical texts in illuminating the economic infrastructure that underpinned the prominence of Makassar between the early 16th and middle 17th centuries. Examples of how these two sources of information complement each other are set out below:

Rice. The importance of wet rice for the Talloq economy is not obvious from the kingdom's associated historical sites, whose potential for wet-rice production appear limited. However, the Talloq chronicle notes wet-rice planting as a royally sponsored activity. Obversely, the Gowa chronicle makes minimal reference to wet-rice but its central economic importance to the kingdom is abundantly clear from the physical location of historical sites within Gowa's core territory that are islands within seas of rice fields, or at the margins of paddy-laid depressions.

Central places. The Gowa and Talloq centres of political power correspond to distinct clusters of historical sites which, in the case of the Gowa hinterland centres, were additionally ringed by halos of smaller sites. These appear to have been continuous population centres from the early 16th to middle 17th centuries, even when one centre temporarily rose in prominence above another due to internal political machinations. They were thus the geopolitical landscape upon which prominent Gowa and Talloq individuals pursued their political ambitions.

Centre and expansion. The military achievements of Gowa and Talloq in conquering and/or subduing their neighbours (McWilliam et al. 2012) lie outside this article's scope but the marital alliance patterns of the main Makassar patrilines over time that are analysed in detail were an important component of this achievement. These patterns should be understood not only within the context of the overall outline of Makassar's history-as above-but also with regard to the high population densities within Makassar and its environs that made maintenance of internal marital alliances a priority at all times.

As a concluding remark, it is worth noting that some details of my previous analysis (Bulbeck 1992; 1996) of the Makasar texts have changed 
with reference to Cummings' $(2007 ; 2011)$ scholarly translations of the chronicles and diaries. For instance, the status of Maros as an early 16th century karaengship of Gowa was not previously clear and it is now possible to trace the Tumailalang patriline with more confidence. On the other hand, the general outline of my previous analysis, including the clear differences in marriage alliance patterns between the circa 16th century, 1593-1667 and 1667-1700 periods, remains intact. The Makasar texts are particularly valuable for their detail of information that facilitates insightful quantitative analysis and allows documentary evidence to be productively related to the archaeological record.

\section{ENDNOTES}

* David Bulbeck is a specialist in the late prehistoric and historical archaeology of Sulawesi. His PhD (obtained from the Australian National University), investigated the rise of Makassar as a city-state through an analysis of Makassar's genealogical records and a reconstruction of the 14th to 17th century settlement patterns in Makassar's hinterland. His postdoctoral research, undertaken jointly with Ian Caldwell (then at the University of Hull), documented the prehistoric origins and pre-Islamic history of iron production in Luwuq, northwest of Makassar. Currently he is employed with "The Archaeology of Sulawesi: A Strategic Island for Understanding Modern Human Colonization and Interactions across Our Region" project, funded by the Australian Research Council to the Australian National University.

1 In this article Makassar refers to the historical kingdom and empire of the Makasars. Makasar (with one "s") refers to the ethnic group of that name and their language.

2 For a discussion on Makasar and Bugis chronicles see Macknight (2000) and Druce (2009: 66-72), also Druce (2016). For diaries see Cense (1966), Omar (2003) and Cummings (2011).

Both texts were given to me by Campbell Macknight.

4 This Excel spreadsheet is available on request from me.

5 Investigating this possibility would require a sampling of Makassar's early historical genealogical relationships that is less "top-heavy" than the available sampling.

6 The status of Kale Gowa as Gowa's centre is attested by the archaeological documentation of a 84-hectare fortress that encloses Gowa's royal installation stone, other ancient ceremonial installation sites, several royal and/or holy cemeteries, and evidence from surface survey of dense habitation (Bulbeck 1992).

7 An example of one who did not is the Karaeng of Anaq Goa, a place located across the Jeqneqberang from Kale Goa as shown in Figure 1, who was a son of the Gowa ruler Tunipalangga but died at a young age.

8 Connecting the Talloq fortress survey to the continuously surveyed area was not practical because most of the intervening land had undergone urban and suburban developed by the time of my survey, and connecting the Sanrabone fortress survey to the continuously surveyed area was not achieved owing to lack of time. 
9 Two of these toponyms, Boriqsallo and Manuju (Figure 7), can now be identified with more probable locations than are given in Bulbeck (1992). Manuju frequently occurred as a member of Gowa's Bate Salapang (nine banners) according to Mukhlis (1975). The locations of the Bate Salapang are included in Figures 7 and 8.

\section{REFERENCES}

Andaya, L. Y. 1981. The heritage of Arung Palakka. The Hague: Martinus Nijhoff. Bulbeck, F. D. 1990. The landscape of the Makassar War. Canberra Anthropology 13 (1): 78-99, http://dx.doi.org/10.1080/03149099009508490. . 1992. A tale of two kingdoms: The historical archaeology of Gowa and Tallok, South Sulawesi, Indonesia. PhD diss., Canberra, Australian National University. . 1996-1997. The Bronze-Iron Age of South Sulawesi, Indonesia: Mortuary traditions, metallurgy and trade. In Ancient Chinese and Southeast Asian Bronze Age cultures, vol. II, eds. Bulbeck, F. D. and Barnard, N., 10071076. Taipei: Southern Materials Center.

. 1996. The politics of marriage and the marriage of polities in Gowa, South Sulawesi, during the 16th and 17th Centuries. In Origins, ancestry and alliance, eds. Fox, J. J. and Sather, C., 280-315. Canberra: Australian National University Press.

Cense, A. 1966. Old Buginese and Macassarese diaries. Bijdragen tot de Taal-, Land- en Volkenkunde 122 (4): 416-428.

Cummings, W. P. 2007. A chain of kings: The Makassarese chronicles of Gowa and Talloq. Leiden: KITLV Press. .2011. The Makassar annals. Leiden: KITLV Press.

Druce, S. C. 2009. The lands west of the lakes: A history of the Ajattappareng kingdoms of South Sulawesi, 1200 to 1600 CE. Leiden: KITLV Press.

. 2016. Transmitting the past in South Sulawesi: The hikajat Sawitto and other Bugis and Makasar historical works. In Orality, writing and history: The literature of the Bugis and Makasar of South Sulawesi, ed. Druce, S. C. International Journal of Asia Pacific Studies 12 (Supp. 1): 73-117, http://dx.doi.org/10.21315/ijaps2016.12.s1.5.

Kamaruddin, H. D. et al. 1985. Lontarak bilang Raja Gowa dan Tallok (naskah Makassar). Ujung Pandang: Proyek Penelitian dan Pengkajian Sulawesi Selatan Lagaligo, Departemen Pendidikan dan Kebudayaan.

Ligtvoet, A. 1880. Transcriptie van het dagboek der vorsten van Gowa en Tello. Bijdragen tot de Taal-, Land- en Volkenkunde 28 (1): 5-54, http://dx.doi.org/10.1163/22134379-90000511.

McWilliam, A. et al. 2012. The cultural legacy of Makassar stone in East Timor. Asia Pacific Journal of Anthropology 13 (3): 262-279, http://dx.doi.org/10.1080/14442213.2012.674054. 
Macknight, C. C. 2000. South Sulawesi chronicles and their possible models. In Vasco da Gama and the linking of Europe and Asia, ed. Disney, A. and Booth, E., 322-332. New Delhi: Oxford University Press.

Mukhlis. 1975. Struktur birokrasi kerajaan Gowa jaman pemerintahan Sultan Hasanuddin (1653-1669). Postgraduate diss., Universitas Gadjah Mada, Yogyakarta.

Noorduyn, J. 1991. The manuscripts of the Makasarese chronicle of Goa and Talloq: An evaluation. Bijdragen tot de Taal-, Land- en Volkenkunde 147 (4): 454-484.

Omar, R. 2003. The history of Boné A. D. 1775-1795. The diary of Sultan Ahmad as-Saleh Syamsuddin. PhD diss., University of Hull, United Kingdom.

Patunru, D. A. R. 1983. Sejarah Gowa. Ujung Pandang: Yayasan Kebudayaan Sulawesi Selatan.

Rahim, A. and Ridwan, B. 1975. Sejarah kerajaan Tallo' (suatu transkripsi lontara'). Ujung Pandang: Kantor Cabang II Lembaga Sejarah dan Antropologi.

Reid, A. 1983. The rise of Makassar. Review of Indonesian and Malaysian Affairs 17: $117-160$.

1993. Southeast Asia in the age of commerce, vol. 2: Expansion and crisis. New Haven: Yale University Press.

Wolhoff, G. J. and Abdurrahim. 1959. Sedjarah Gowa. Ujung Pandang: Jajasan Kebudayaan Sulawesi Selatan dan Tenggara. 